\title{
ELECTRONEUROMYOGRAPHY AND NEUROMUSCULAR FINDINGS IN 16 PRIMARY HYPOTHYROIDISM PATIENTS
}

\author{
MÁRCIA W. CRIZ*; MAURO TENDRICH**; MÁRIO VAISMAN**; SÉRGIOA. P. NOVIS*
}

\begin{abstract}
There has been few reports on electroneuromyography (ENMG) changes in hypothyroidism. The objectives of the present study were to investigate the frequency of ENMG abnormalities in hypothyroidism and correlate them with neurological signs and symptoms and muscle enzyme levels; and to compare latency, amplitude and nerve conduction velocity from selected nerves with controls. Sixteen patients suffering from primary hypothyroidism were submitted to ENMG before treatment. ENMG abnormalities were found in $87.5 \%$ of the patients; $46.6 \%$ had myopathy and $43.7 \%$ had carpal tunnel syndrome. There was no case of polyneuropathy. A clear-cut clinical, laboratorial and ENMG correlation was observed in patients with myopathy and carpal tunnel syndrome. The patients showed a significant tendency of nerve conduction slowness as compared with controls. The findings are in accordance with the well-known nerve and muscle damage in hypothyroidism.
\end{abstract}

KEY WORDS : primary hypothyroidism, electroneuromyography, carpal tunnel syndrome, myopathy.

\section{Achados eletroneuromiográficos e neuromusculares em 16 pacientes com hipotireoidismo primário}

RESUMO - Foram avaliados através de eletroneuromiografia (ENMG) 16 pacientes com hipotireoidismo primário de diversas etiologias, virgens de tratamento, com o objetivo de: estabelecer a incidência de alteraçōes; correlacioná-las com parâmetros clínicos referentes ao acometimento do sistema nervoso periférico e níveis de enzimas musculares; estabelecer a comparaçāo entre valores médios da latência, amplitude e velocidade de conduçăo nervosa de alguns nervos selecionados no grupo de pacientes e de grupo controle. Alteraçôes da ENMG foram encontradas em 87,5\% dos casos, sendo estabelecido diagnóstico eletrofisiologico de miopatia em 46,6\% e de síndrome do túnel do carpo em 43,7\%. Nenhum dos casos foi identificado como polineuropatia. A concordância entre sintomatologia $(100 \%)$, exame neurológico $(28,57 \%)$, níveis de enzimas musculares $(42,85 \%)$ e ENMG foi elevada para casos de miopatia. Nos casos de síndrome do canal carpiano foi respectivamente de $71,42 \%$ para sintomatologia e $71,42 \%$ para exame neurológico. A comparação de valores médios dos parâmetros selecionados de neurocondução, entre pacientes e controle, demonstrou tendência generalizada à lentificação da condução nervosa no hipotireoidismo primário. A literatura revista concorda com os dados dos autores em relaçăo à extensão do dano de nervo e músculo nessa endocrinopatia.

PALAVRAS-CHAVE: hipotireoidismo primário, eletroneuromiografia, síndrome do túnel do carpo, miopatia.

Primary hypothyroidism is a chronic and insidious disease caused by failure of thyroid hormone production mostly due to inflammation, thyroidectomy, use of I 131, and anti-hyperthyroidism drugs. A wide variety of systems may be affected, such as renal, digestive, cardiac, circulatory and nervous. The nervous system may be damaged centrally or peripherally. Dysfunction of the peripheral nerve system (PNS) is not infrequent and should prompt correct diagnosis and treatment of this endocrinopathy when present. Early treatment provides overall clinical amellioration. The so called myxedematous myopathy represents 5 to $10 \%$ of acquired myopathies ${ }^{6.9}$. This myopathy, in its full expression, is unusual but by their time, frequent are complaints as weakness ${ }^{14,19}$, cramps $^{3,19}$, and stiffness. Slowness of relaxation time of deep reflexes is found in $80 \%$ of the cases ${ }^{10}$. Thus, it should

*Neurology and **Endocrinology Departments, Clementino Fraga Filho University Hospital, Federal University of Rio de Janeiro. Aceite: 11-setembro-1995.

Dra. Marcia Waddington Cruz - Rua Conselheiro Paulino 348 - 21073-240 Rio de Janeiro RJ - Brasil. 
be considered that the real incidence of muscle dysfunction may be underestimated. Hyposthesia ${ }^{13}$, pain and paresthesias ${ }^{2 A}$, deep reflexes hyporreplexia, atrophy, hyposthesia and disautonomy ${ }^{2}$ may be present in hypothyroidism. The electrophysiological diagnosis of peripheral neuropathy reaches $72 \%$ of cases in some series ${ }^{1}$. The real prevalence of hypothyroidism neuropathy and/or myopathy depends on the diagnostic criteria used, either clinical, electrophysiological, laboratorial, structural or combined. In addition, most available data published are case reports. In only few of them the prevalence of such disorders was infered.

The objectives of the present study are: to report the prevalence of clinical, laboratorial and electroneuromyography (ENMG) alterations related to nerve and/or muscle lesions in hypothyroidism; to estimate the prevalence of hypothyroidism neuromuscular disorders defined by ENMG criteria; to relate them to signs and symptoms of PNS dysfunction; and compare mean values of some selected topics of nerve conduction studies between patients and controls.

\section{MATERIAL AND METHODS}

Sixteen patients (14 women and 2 men), mean age of 43 years (23-70) with primary hypothyroidism of various etiologies were evaluated before any treatment.

Endocrinological diagnosis was based on anamnesis, physical examination, determination of basal serum levels of T3, T4, free T4 and TSH (RIE method, DPC kits) and 30 and 60 minutes after injection of $200 \mathrm{mg}$ of TRH (EPM, FUNDAP), and detection of antithyreoglobulin and antiperoxidase antibodies (hemagglutination).

Table I. Nerve conduction studies.

\begin{tabular}{|c|c|c|c|c|c|c|c|c|c|c|}
\hline Patients & TML & $\downarrow_{M C V}$ & $\begin{array}{l}\downarrow M A \text { or } \\
\text { Abolition }\end{array}$ & CB & $\begin{array}{l}\text { TP wave } \\
\text { Lantency }\end{array}$ & $\begin{array}{l}\text { TH Reflex } \\
\text { Lantecy } \\
\text { or Abolition }\end{array}$ & TSL & LSCV & $\begin{array}{l}\text { LSA or } \\
\text { Abolition }\end{array}$ & CTS \\
\hline
\end{tabular}

\begin{tabular}{llllllllllll}
\hline 1 & - & - & - & - & - & - & - & - & - & - \\
2 & - & - & + & + & + & - & - & - & + & - \\
3 & - & - & - & + & - & - & - & - & + & - \\
4 & - & - & - & - & - & - & - & - & + & - \\
5 & - & - & - & - & + & + & + & + & + & + \\
6 & - & + & - & - & - & - & + & + & + & + \\
7 & + & + & + & - & - & - & - & - & + & + \\
8 & - & - & - & - & - & - & + & + & + & + \\
9 & + & - & - & - & - & - & - & + & + & + \\
10 & - & - & - & + & - & + & - & - & - & - \\
11 & - & - & - & - & - & - & - & - & - & - \\
12 & - & - & - & - & - & - & - & - & + & - \\
13 & - & + & - & - & - & - & - & - & - & + \\
14 & - & + & - & - & - & - & - & - & + & - \\
15 & - & - & - & - & - & - & - & - & + & - \\
16 & - & - & - & - & - & - & + & + & + & + \\
$\%$ & 12,5 & 25 & 12,5 & 18,7 & 12,5 & 18,7 & 25 & 31,2 & 68,7 & 43,7 \\
\hline
\end{tabular}

(1), increased; ( $\downarrow)$, reduced; (+), present; (-), absent; CB, reduction of more them $20 \%$ of proximal MA, without temporal dispersion, avoiding entrapment sites.

Material presented at the XV" World Congress of Neurology (Vancouver, Sept. 1993). 
Table 2. EMG results.

\begin{tabular}{|c|c|c|c|}
\hline Patients & EMG Findings & Muscle (S) & EMG MyopaticC \\
\hline 1 & Normal & - & - \\
\hline 2 & Reduced muap & Deltoid & + \\
\hline 3 & Normal & - & - \\
\hline 4 & Normal & $\cdot$ & - \\
\hline 5 & Paradoxal interference pattern & Deltoid & + \\
\hline 6 & Normal & - & - \\
\hline 7 & $\begin{array}{l}\text { Paradoxal interference pattern } \\
\text { Positive waves discharges after needle inserction }\end{array}$ & $\begin{array}{c}\text { Deltoid } \\
\text { Gastrocnemius }\end{array}$ & + \\
\hline 8 & Normal & - & - \\
\hline 9 & $\begin{array}{l}\text { Neurogenic recruitment type } \\
\text { Positive waves discharges after needle inserction } \\
\text { Fasciculations }\end{array}$ & $\begin{array}{l}\text { Abductor pollicis brevis } \\
\text { Deltoid } \\
\text { Deltoid }\end{array}$ & + \\
\hline 10 & Muap poliphasic & $\begin{array}{l}\text { Deltoid } \\
\text { Quadriceps } \\
\text { Tibialis Anterior }\end{array}$ & + \\
\hline 11 & Normal & - & - \\
\hline 12 & Positive waves & Quadriceps & + \\
\hline 13 & Normal & - & - \\
\hline 14 & Normal & - & - \\
\hline 15 & Not done & & \\
\hline 16 & $\begin{array}{l}\text { Positive waves/fibrilation } \\
\text { Fasciculations } \\
\text { Muap poliphasia } \\
\text { Reduced muap amplitude } \\
\text { Complexe repetitive discharges }\end{array}$ & $\begin{array}{l}\text { Deltoid / Gastrocnemius } \\
\text { Gastrocnemius } \\
\text { Gastrocnemius } \\
\text { Deltoid }\end{array}$ & + \\
\hline
\end{tabular}

(+), present; (-), absent.

Inclusion criteria were : low T3 and T4 and elevated TSH levels; normal T3, low T4 and high TSH levels, and finally normal T3, T4 and TSH basal levels, with TSH obvious elevation 30 minutes after TRH injection. Patients with high serum glicose levels, diabetic or not, with history of contact with toxic substances to the nerve and muscle including alcohol or with other obvious causes of neuromuscular disease were excluded.

The ENMG study included: 1) Motor nerve conduction studies - Determination of motor latency (ML), motor amplitude (MA) and motor conduction velocity (MCV) in peroneal, tibial, median and ulnar nerves bilaterally (including MCV of ulnar nerve through the elbow). 2) Sensory nerve conduction studies - Determination of sensitive latency (SL), sensitive amplitude (SA) and sensitive conduction velocity (SCV) of sural (antidromic), radial, median and ulnar (orthodromic digit 1 through 5 - wrist) nerves bilaterally. Latencies and SCV between the median and ulnar nerves after stimulus to the $4^{\text {th }}$ finger were compared. Palm-wrist conduction velocity of median nerve was also determined (stimulus $8 \mathrm{~cm}$ distal to active electrode on the wrist). 3) Latency and amplitude of $\mathrm{H}$ reflex of tibial nerve bilaterally were determined, and also a righ-left comparison was performed. 4) Minimal latency determination of F waves of left ulnar and tibial nerves. 5) Electromyography - Nerve conduction studies were followed by concentric needle examination of the tibialis anterior, quadriceps and deltoid muscles. Gastrocnemius, abdutor pollicis brevis, abdutor digitis minimi and flexor carpi ulnaris were also studied in selected cases with putative myopathy, carpal tunnel syndrome or ulnar neuropathy, respectively. 
Table 3. Presence of CTS and/or myopathy.

\begin{tabular}{lr}
\hline CTS & $43.7 \%(7 / 16)$ \\
MYOPATHY & $46.6 \%(7 / 17)$ \\
CTS + MYOPATHY & $25 \%(4 / 16)$ \\
\hline
\end{tabular}

Examinations were performed using a 2 channel Nihon Kohden Neuropack 2 electromyography apparatus. Room temperature was maintained above $25^{\circ} \mathrm{C}$. The same examinator collected data. Superficial electrodes were employed for both stimulus and register (Nihon Kohden).

Peripheral neuropathy was considered when 3 or more parameters were found abnormal in at least 3 different nerves.

Lesion of the median nerve at the wrist (carpal tunnel syndrome, CTS) was established based on absolute values of distal motor and/or sensory latencies; SCV between digit-wrist and/or palm-wrist; and comparative values of latencies and SCV between median and ulnar nerves after stimulus to the $4^{\text {th }}$ digit.

Mean values of ML, MA and MCV of peroneal nerve, $H$ reflex latency; tibial nerve $F$ wave minimal latency; ML, MA and MCV of median nerve; ML, MA and MCV through elbow of ulnar nerve; SL, SA and SCV of sural nerve; SL, SA and SCV 4 finger wrist and palm-wrist of median nerve; and finally SL and SCV of ulnar nerve, after stimulus to the $4^{\text {th }}$ finger, were compared to mean values obtained from 54 healthy controls (mean age of 39 years) by Student t-Test at a significance level of $5 \%$.

Table 4. Nerve conduction studies.

\begin{tabular}{|c|c|c|c|c|}
\hline Nerve & Values & $\begin{array}{l}\text { Patients (SD) } \\
\text { means }\end{array}$ & $\begin{array}{c}\text { Controls (SD) } \\
\text { means }\end{array}$ & $\mathbf{P}$ \\
\hline \multirow[t]{3}{*}{ Peroneal } & ML & $3.9(0.55)$ & $3.6(0.8)$ & 0.05 \\
\hline & MA & $5.9(2.16)$ & $5.6(2.12)$ & - \\
\hline & MCV & $48.3(3.64)$ & $49.4(3.51)$ & NS \\
\hline \multirow[t]{2}{*}{ Tibial } & $\mathrm{FW}$ & $44.7(4.66)$ & $43.1(13.49)$ & NS \\
\hline & HR & $31.8(3.47)$ & $31.7(1.52)$ & - \\
\hline \multirow[t]{3}{*}{ Median } & ML & $3.5(1.92)$ & $2.7(0.38)$ & 0.025 \\
\hline & MA & $5.7(1.86)$ & $5.6(2.05)$ & - \\
\hline & $\mathrm{MCV}$ & $54.3(7.08)$ & $50.5(21.88)$ & - \\
\hline \multirow[t]{3}{*}{ Ulnar } & ML & $2.5(0.41)$ & $2.4(0.41)$ & - \\
\hline & MA & $7.9(2.22)$ & $8.2(1.79)$ & NS \\
\hline & MCV (through elbow) & $58.9(8.01)$ & $53.7(3.33)$ & - \\
\hline \multirow[t]{3}{*}{ Sural } & SL & $3.3(0.29)$ & $3.11(0.25)$ & 0.025 \\
\hline & SA & $26.1(19.01)$ & $22.6(13.91)$ & - \\
\hline & SCV & $42.8(3.97)$ & $45.3(3.93)$ & 0.025 \\
\hline \multirow[t]{4}{*}{ Median IV digit } & SL & $2.4(0.35)$ & $2.3(0.27)$ & NS \\
\hline & SA & $44.3(38.73)$ & $30.9(22.26)$ & - \\
\hline & SCV & $54.5(7.64)$ & $58.5(6.47)$ & 0.05 \\
\hline & Palm-wrist & $56.7(9.88)$ & $59.7(7.28)$ & NS \\
\hline \multirow[t]{3}{*}{ Ulnar IV Digit } & SL & $2.3(0.31)$ & $2.3(0.31)$ & - \\
\hline & SA & $32.2(31.57)$ & $28.1(24.79)$ & - \\
\hline & SCV & $56.5(7.41)$ & $55.2(7.19)$ & - \\
\hline
\end{tabular}


The following muscle enzymes levels were determined : CPK - Klin and col., BPC; CPK - MB - Wiirzbury and col., Merck; LDH - Chemil and col. method, Merck; Aldolase - Sibley and col., BMB.

\section{RESULTS}

Increased basal TSH or abnormal elevation after TRH injection confirmed the diagnosis of hypothyroidism in all but 2 patients Cases 5 and 12. In Case 5, low levels of T3, T4 and free T4, in addition to the presence of antithyroid antibodies and concordant symptoms, stablished the diagnosis. In Case 12, T3, T4 and free T4 were at normal levels and diagnosis was based on symptoms and the presence of high levels of antibodies. In both cases TRH test was not available.

Cramps was the most refered symptom (43.7\%) followed by paresthesias on hands $(68.7 \%)$, weakness $(62.5 \%)$, dysphagia and/or dysphonia $(50 \%)$, stiffness $(43.7 \%)$, ptosis (25\%), diplopia and muscular hypertrophy $(12.5 \%)$.

At neurological examination hypo or arreflexia was mostly noted $(81.2 \%)$ followed in frequency by : muscle pain (37.5\%), Tinnel sign after percussion of median nerve at the wrist $(31.2 \%)$, distal hyposthesia on median nerve distribution (12.5\%) and muscle weakness (12.5\%). The acuillean reflex was abolished in $31 \%$ of the patients and hypoactive in $31 \%$. Biceps, triceps and patellar reflexes were found diminished in $56 \%, 31 \%$ and $25 \%$ of the cases respectivelly.

Table 1 lists the findings on nerve conduction studies. Reduction or abolition of SA was the most frequent finding $(68.7 \%)$. CTS was established in $43.7 \%$ of the cases.

At Table 2 EMG results can be seen. Myopathic pattern was noted in $46.6 \%$ of the patients.

Concomitance of myopathy and CTS as seen by ENMG, occurred in $25 \%$ of the cases (Table 3 ).

Increased levels of muscle enzymes were found on $54,5 \%$ of the cases and in $36,3 \%$ of them only CPK was above normal level.

In all patients that we found some evidence of myopathy by ENMG, related symptoms were present. Weakness was detected on physical examination in only $28.57 \%$ of the cases and muscle enzymes levels were increased in $42.85 \%$. In the two cases presenting weakness at physical examination, myopathy was confirmed by EMG and probably by muscle enzymes elevation. Symptoms were found alone in $40 \%$ of cases.

In $71.42 \%$ of our cases with median nerve lesion at the wrist (CTS) as seen by ENMG, related symptoms were present. Concomitance of neurological signs was also noted in $71.42 \%$ of our cases. Subclinical involvement was found in $14.28 \%$ of cases by ENMG.

Table 4 shows the comparison of mean values of some selected items of nerve conduction between patients and controls. Significant differences were found for ML of peroneal and median nerves, SL of sural nerve and SCV of sural and median nerves in the group of patients.

\section{DISCUSSION}

Conceming the neurological involvement, its prevalence can hardly be compared with previous literature. Cramps were mostly refered (75\% of cases). It is mentioned in one third of cases in other series $^{3,14}$. Paresthesias were found in $68.7 \%$ in accordance with $47 \%$ and $64 \%$ found in other series ${ }^{2,4}$. The prevalence of muscle weakness seems to vary widely in such patients $\left(47 \%{ }^{2}, 64 \%{ }^{4}\right)$. In the present study, $62.5 \%$ of the patients complained of weakness. The actual incidence of weakness remains to be determined. To the best of our knowledge, percent incidence of other neurological symptoms have not been reported.

At neurological examination, hyporreflexia was mostly noted $(81.2 \%)$, in contrast to $33 \%^{2}, 4 \%^{3}$ and $8 \%$ in the literature. Superficial distal hyposthesia was observed in $12.5 \%$ of cases and in $60 \%$ of 
cases by others ${ }^{13,18}$. For the remaining signs no comparison was possible in view of the lack of mention of prevalence in the series reviewed although they were consistently refered in case reports.

Dysphonia, ptosis, diplopia, muscle hypertrophy and abnormal gait were never observed on neurological examination either because they were relapsing symptoms or misunderstood by the patients. Also, muscle weakness was reported in $62.5 \%$ of the cases and found at examination only in $6.25 \%$. The remaining patients probably refered asthenia. Paresthesias $(68.7 \%)$ were followed by hyposthesia in $12.5 \%$ of cases only.

Myalgia (37.5\%) may be related to forms resembling polymyositis as it is refered in the literature ${ }^{21}$.

As far as nerve conduction findings are concerned, reduction or abolition of SA was noted in 68.7\%. Median nerve compromise at the wrist (CTS) was the second most frequent finding and accounted for the majority of abnormalities of SA. Technical problems must also be taken into account in myxedematous patients in this respect. The use of comparative values of SL and SCV provided more accurate diagnosis of CTS. Murray and Simpson ${ }^{16}$ detected only CTS but they studied exclusively median and ulnar nerves. Other authors found a more widespread neuropathy 2,7.11.12.22.26.

Begin et al. ${ }^{1}$ defined polyneuropathy whenever 2 values were found abnormal on nerve conduction study. This was present in $72 \%$ in their series. We employed more strict criteria in order to avoid misinterpretation of technical artifacts. None of our cases was considered as having polyneuropathy. However, some authors have reported primary demyelination ${ }^{6.16,23}$ and others secondary demyelination ${ }^{11,15,17}$ on nerve biopsies.

Muscle involvement was established at needle examination in $46.6 \%$ of cases. Scarpazelos et al. ${ }^{22}$ refered $27.45 \%$ and Rao et al. ${ }^{20} 70 \%$. The real incidence remains undetermined.

The association of myopathy and CTS (25\% of our cases) is well known ${ }^{12,20,22,24,26}$.

Muscle enzymes levels might be related to the metabolic disturbance of hypothyroidism rather than to muscle lesion.

Comparing mean values of latencies and amplitudes from nerves of patients and controls, a significant slowness of nerve conduction in the patients group was found, (significative greater SL and shorter SCV in some nerves in the patients group).

Amplitude values were not found significantly different in patients, probably reflecting the axonal integrity. This slowness of nerve conduction may represent the more widespread nerve involvement otherwise mentioned and not recognized by our ENMG criteria as polyneuropathy and might justify the presence of hyposthesia and paresthesias in $93.7 \%$ of our patients. Fincham and Cape $^{7}$ making the same comparison, also found a significant difference for median and ulnar nerves conduction. Rao et al. ${ }^{20}$, found it only in the median nerve.

Thyroid hormones levels were not compared to ENMG as all alone they could not be considered good indicators of the disease severity. In previous studies such a correlation was not detected ${ }^{3,16,22,25}$.

\section{CONCLUSIONS}

1. ENMG was found abnormal in $87.5 \%$ of cases. In $62.5 \%$, myopathy (46.6\%) or CTS (43.7\%) was established.

2. In all cases defined as myopathy by EMG, symptoms were present, abnormal neurological examination was found in $28,57 \%$ of them and high muscle enzymes levels in $42.85 \%$.

3. No case of putative polyneuropathy was recognized by our ENMG criteria.

4. $71.42 \%$ of cases classified as CTS by ENMG had symptomatology and with the same incidence, Tinel sign and median nerve territory hyposthesia were observed. 
5. The comparison of mean values of some topics of ENMG between patients and controls characterised the slowness of nerve conduction in patients, overpassing the median nerve territory. 6. The high incidence of myopathy and CTS defined by ENMG and their concordance with symptoms and physical examination, clarifies nerve and muscle damage in primary hypothyroidism and justifies its inclusion in the differential diagnosis of secondary myopathy and/or neuropathy, entrapment types included, overall because it prompts efficient treatment when early in the course of illness.

\section{REFERENCES}

1. AAEM Guideliness in electrodiagnostic medicine. Muscle and Nerve 1992; 15:229-253.

2. Beghi E, Delodovici ML, Bogliun G, Crespi V, Paleari F, Gamba P, Carpa M, Zarreli M. Hypothyroidism and polyneuropathy. J Neurol Neurosurg and Psychiatry 1989; 52:1420-1423.

3. Buge A, Martier M. Manifestations musculaires de l'hypothyróidie. Rev Practic, 1968; 18:2184.

4. Crevasse LE, Logue RB. Peripheral neuropathy in myxedema. Ann Intern Med 1959; 50:1433-1437.

5. Cruz MW, Tendrich M, Mattos JP, Vaisman M, Novis SAP. ENMG study in primary hypothyroidism. Can J Neurol Sci 1993, (Suppl 4):S27.

6. Fessel WJ. Myopathy of hypothyroidism. Ann Rheum Dis 1968, 27:590-596.

7. Fincham RW, Cape CA. Neuropathy in myxedema. Arch Neurol 1968; 19:464-466.

8. Kimura J. Electrodiagnosis in diseases of nerve and muscle: principles and practice, Ed 2 Philadelphia: FA Davis, 1989.

9. Klein I, Parker M, Shebert R, Ayyar DR, Levey GS. Hypothyroidism presenting as muscle stiffness and pseudohypertrophy: Hoffman's syndrome. Am J Med, 1981; 70:891-894.

10. Klein I, Levey GS. Unusual manifestations of hypothyroidism. Arch Intern Med 1984, 144:123-128.

11. Lagueny A, Manciet G, Vital A, Ferrer X, Julien J. Neuropathie hypothyroidienne. Rev Neurol (Paris) 1990; 146:205-210.

12. Leroche M, Testut MF, Clanet M, Guirand-Chaumeil B, Rascol A. Neuropathie périphérique hypothyroidiene. Sem Hôp Paris 1986; 62:1153-1156.

13. Martin J, Tomkin GH, Hutchinson M. Peripheral neuropathy in hypothyroidism. an association with spurious polycythaemia (Gaisbock's syndrome). J R Soc Med, 1983; 76:187-189.

14. McKeran RO, Slavin G, Ward P, Paul E, Main WGP. Hypotyroid myopathy: a clinical and pathological study. J Pathol, 1980; 132:35-54.

15. Meier $\mathrm{C}$, Bischoff A. Polyneuropathy in hypothyroidism: clinical and nerve biopsy study of four Cases. J Neurol 1977; 215:103-114.

16. Murray IPC, Simpson JA. Acroparaesthesia in myxoedema: a clinical and electromyographic study. Lancet 1958, 1:1360-1363.

17. Nemni R, Bottacchi E, Fazio R, Mamoli A, Corbo M, Camerlingo M, Galandi G, Erenbourg L, Canal N. Polyneuropathy in hypothyroidism clinical, electrophysiological and morphological findings in four cases. J Neurol Neurosurg Psychiatry 1987; 50:1454-1460.

18. Nickel SN, Frame B, Bebin J, Tourtellotte WW, Parker JA, Hughes BR. Myxedema neuropathy and myopathy: a Clinical and pathologic study. Neurology 1961,11:125-137.

19. Pandolfi C, Filippi C. Sindrome di Guillain-Barré associata a ipotiroidismo. Min Med, 1989; 80:11291131.

20. Rao SN, Katiyar BC, Nair KRP, Missa S. Neuromuscular status in hypothyroidism. Acta Neurol Scand, $1980 ; 61: 167-177$.

21. Salvarani C, Marcello N, Macchioni P, Guidetti D, Rossi F, Iori I, Baricchi R, Ghirelli L, Postioli I. Hypothyroidism simulating polymyositis, J Neurol Neurosurg Psychiatry 1988; 17:147-149.

22. Scarpalezos S, Lygidakis C, Papageorgiou C, Maliara S, Koukoulommati AS, Kontras DA. Neural and muscular manifestations of hypothyroidism. Arch Neurol 1973; 29:140-144.

23. Shirabe T, Tawara S, Terao A, Araki S. Myxoedematous polyneuropathy: a light and electron microscopic study of the peripheral nerve and muscle. J Neurol Neurosurg Psychiatry 1975; 38:241-247.

24. Torres CF, Moxley RT. Hypothyroid neuropathy and myopathy: clinical and electrodiagnostic longitudinal findings. J Neurol 1990; 237:271-274.

25. Wladstein SS, Bronsky D, Shifter HB, Oester YT. The electromyogram in myxedema. Arch Intern Med $1958 ; 101: 97-101$.

26. Zampollo A, Cristofori E, Zacchetti O, Spreafico A. Casistica clínica. In Tema di neuropatia hipotiroidea. Min Med, 1983, 74:165-172. 